\title{
EARLY GROWTH MODEL OF PELIBUEY LAMBS RAISED UNDER AN INTENSIVE PRODUCTION SYSTEM IN COLIMA, MEXICO
}

\author{
Rafael Macedo ${ }^{1 \mathrm{a} *}$, Victalina Arredondo $^{1 \mathrm{~b}}$, Ana Jiménez ${ }^{1 \mathrm{c}}$, Carlos Haubi ${ }^{2}$, and Alejandra Herrera ${ }^{3}$ \\ 1a Universidad de Colima, Facultad de Medicina Veterinaria y Zootecnia, Km. 40 Autopista Colima - \\ Manzanillo, Tecomán, Colima, Mexico \\ https://orcid.org/0000-0002-9742-7857 \\ ${ }^{1 b}$ Universidad de Colima, Facultad de Medicina Veterinaria y Zootecnia, Km. 40 Autopista Colima - \\ Manzanillo, Tecomán, Colima, Mexico \\ https://orcid.org/0000-0002-5577-1545 \\ 1c Universidad de Colima, Facultad de Medicina Veterinaria y Zootecnia, Km. 40 Autopista Colima - \\ Manzanillo, Tecomán, Colima, Mexico \\ https://orcid.org/0000-0002-6473-5116 \\ ${ }^{2}$ Universidad Autónoma de Aguascalientes, Departamento de Ciencias Veterinarias, Km. 3 Carretera \\ Jesús María - La Posta, Jesús María, Aguascalientes, Mexico \\ https://orcid.org/0000-0002-7963-4705 \\ ${ }^{3}$ Universidad Autónoma de San Luis Potosí, Facultad de Agronomía y Medicina Veterinaria, Km. 14.5 \\ Autopista San Luis - Matehuala, Soledad de Graciano Sánchez, San Luis Potosí, México https://orcid. \\ org/0000-0001-9655-1867 \\ * Corresponding author E-mail: macedo@ucol.mx
}

\section{ABSTRACT}

The aim of this study was to describe the early growth of Pelibuey lambs raised under an intensive production system in Colima, Mexico, using non-linear models. Weight data were collected from 433 lambs every 30 days from birth to 180 days of age, and growth curves were estimated using non-linear and linear models. According to goodness of fit criteria, the Linear, Gompertz, Logistic and Von Bertalanffy models are suitable and show a reasonable fit for describing Pelibuey lamb's growth, the Brody and Richards curves did not meet the convergence criterion. The parameter A denotes asymptotic weight; weight was higher in multiple born males and quadruplet born females in the Von Bertalanffy and Gompertz models, while it was also higher in males in the Logistic model. The parameter $\mathrm{k}$ represents maturation rate and indicates the growth speed in reaching asymptotic weight, being higher in single and twin females, and single males in all the non-linear models. From birth up to 90 days of age (weaning), weight of single lambs becomes greater than that of multiple born lambs, but from 90 days of age, weight of multiple born lambs tends to equal that of singles, which happens at 180 days of age. The early growth of Pelibuey lambs can be described with similar precision using linear and non-linear models.

Key words: Body weight, growth, hair sheep, linear model, non-linear models. 


\section{INTRODUCTION}

Pelibuey is one of the most important breeds of sheep in Mexico. It is characterized by its high adaptability to all agro-ecological regions, showing high fertility, prolificity rates and lack of seasonality (Macedo and Alvarado, 2005; Macedo and Arredondo, 2008; Hernández Montiel et al., 2020). In fact, under intensive fattening conditions, Pelibuey lambs show an outstanding productive performance (Macedo et al., 2009; Resendiz et al., 2013).

Along with other hair breeds, Pelibuey breed is mainly exploited in extensive and subsistence production systems characterized by a low productive and economic efficiency (HernándezBautista et al., 2017; Martínez-Peña et al., 2018; Vázquez-Martínez et al., 2018). This low efficiency is to a large extent a consequence of the low productive potential of sheep, and therefore it is important to implement genetic improvement programs based on the evaluation of the productive performance of lambs (GonzálezVázquez et al., 2015).

Selection programs aiming at improving productive parameters, such as growth rate, body weight and other important commercial features, such as precocity and carcass quality, have been carried out using growth functions as selection criteria (Lupi et al., 2015; Waheed et al., 2016; Hoijati and Hossein-Zadeh, 2018). Growth is best described by the sigmoidal relationship between age and body weight (Lupi et al., 2015). In this sense, the most widely used methods to describe weight are the Brody, Gompertz and Logistic models (Waheed et al., 2016; Hojjati and HosseinZadeh, 2018; Hossein-Zadeh and Golshani, 2016) since they provide a set of mathematical and biological parameters that are used to fit growth curves, describe growth pattern over time, and estimate the expected weight of the animal at specific ages.

Biological growth is defined as the weight gain of an animal until it reaches adulthood, whereas commercial growth is the weight gain during the period comprised between birth and slaughter (Lupi et al., 2015). Analysis of growth curves and parameters through biological and commercial life span is helpful to improve feeding strategies, select the best replacement lambs, and establish the best age for matting and slaughtering (Lupi et al., 2015; Waheed et al., 2016; Hojjati and HosseinZadeh, 2018; Hossein-Zadeh and Golshani, 2016). Therefore, the objective of this study was to describe the early growth of Pelibuey lambs raised under an intensive production system in Colima, Mexico, using non-linear models.

\section{MATERIALS AND METHODS}

Records of 433 Pelibuey lambs were analyzed. The lambs were from a highly prolific purebred flock, and raised under intensive conditions at the Agricultural and Forestry Training Center (CECAF), located in Tecomán, Colima, Mexico $\left(18^{\circ} 58^{\prime} 43^{\prime \prime} \mathrm{N}\right.$; $\left.103^{\circ} 52^{\prime} 18^{\prime \prime} \mathrm{W}\right)$.

From birth to weaning (80 days), feeding consisted of maternal milk plus a commercial creep-feeding containing dry matter $880 \mathrm{~g} \mathrm{~kg}^{-1}$, crude protein $170 \mathrm{~g} \mathrm{~kg}^{-1}$, ether extract $30 \mathrm{~g} \mathrm{~kg}^{-1}$, crude fiber $25 \mathrm{~g} \mathrm{~kg}^{-1}$, nitrogen-free extract $585 \mathrm{~g}$ $\mathrm{kg}^{-1}$, ash $70 \mathrm{~g} \mathrm{~kg}^{-1}$, whose daily consumption was estimated at $100 \mathrm{~g}$. After weaning, the lambs were divided by sex and body weight and fed ad libitum with a concentrate containing dry matter $893 \mathrm{~g} \mathrm{~kg}^{-1}$, crude protein $189 \mathrm{~g} \mathrm{~kg}^{-1}$, nitrogen-free extract $201 \mathrm{~g} \mathrm{~kg}^{-1}$, and metabolizable energy 2.92 Mcal kg DM ${ }^{-1}$.

At birth, each lamb was identified, and weight, sex and litter size were recorded. Subsequently, weight was recorded at 30, 60, 90, 120, 150 and 180 days of age and growth curves were estimated in general, and then considering the effect of sex and litter size. The following nonlinear regression models were used: Brody: $y_{i}$ $=\mathrm{A}^{*}\left(1-\mathrm{B}^{*} \exp \left(-\mathrm{k}^{*} \mathrm{t}\right)\right)+\mathrm{e}_{\mathrm{i}} ;$ Gompertz: $\mathrm{y}_{\mathrm{i}}=\mathrm{A}^{*} \exp (-$ $\left.B^{*} \exp \left(-k^{*} t\right)\right)+e_{i} ;$ Logistic: $y_{i}=A /\left(1+B^{*} \exp \left(-k^{*} t\right)\right)+e_{i}$; Richards: $y_{i}=A /\left(\left(1+k^{*} \exp \left(-B^{*} t\right)\right)^{* *}(1 / m)\right)+e_{i}$; and Von Bertalanffy: $y_{i}=A^{*}\left(1-B^{*} \exp \left(-k^{*} t\right)\right)^{* *} 3+e_{i}$, where: $y_{i}=$ weight in $\mathrm{kg}$ at age $\mathrm{t} ; \mathrm{A}=$ asymptotic weight; $\mathrm{B}=$ integration constant; $\mathrm{k}=$ maturation rate, $\mathrm{m}=$ shape of the growth curve, and $\mathrm{e}=$ error. To select the best curve, the following criteria were considered: the highest value of the coefficient of determination pseudo $\mathrm{R}^{2}$, the lowest value of the Akaike information criterion (AIC), the lowest value of the mean squared error (MSE) and the smallest number of interactions (NI) needed to converge and reach the final value of the parameters. For comparative purposes, a linear regression was fitted to obtain a prediction equation of body weight.

Animal handling complied with national standards NOM-062-ZOO-1999 and NOM-051ZOO-1995 (SENASICA, 2019). Statistical analysis was performed with the statistical software SPSS v. 15.0 .

\section{RESULTS AND DISCUSSION}

According to goodness of fit criteria, the Gompertz, Logistic and Von Bertalanffy models are suitable and show a reasonable fit for describing Pelibuey lamb's growth (Table 1); however, the Brody and Richards curves did not meet the convergence criterion after 
Table 1. Goodness of fit criteria of the Gompertz, Logistic and Von Bertlanffy models.

\begin{tabular}{lcccc}
\hline Model & Pseudo $\mathbf{R}^{2}$ & AIC & MSE & NI \\
\hline Gompertz & 0.87 & 6942.00 & 17.83 & 7 \\
Logistic & 0.87 & 7008.90 & 18.33 & 8 \\
Von Bertalanffy & 0.87 & 6925.00 & 17.70 & 6 \\
\hline
\end{tabular}

AIC: Akaike information criterion; MSE: Mean squared error; NI: Number of interactions.

100 interactions, and thus parameters are not shown. Linear regression analysis produced the prediction equation $\mathrm{y}_{\mathrm{i}}=2.102+0.198(\mathrm{t})$, which showed goodness of fit criteria like those of nonlinear equations $\left(\mathrm{R}^{2}=0.87 ; \mathrm{AIC}=6936.30 ; \mathrm{MSE}=\right.$ 17.79).

Lupi et al. (2015) found that the growth of Segureña lambs was better described by the Von Bertalanffy and Logistic models, while Simanca et al. (2016) reported that the Von Bertalanffy model presented the best fit to describe the growth of Sant Inés $x$ Criollo sheep. Other authors concluded that the Gompertz model was the one that best described the growth of Thalli, Rahmani and Morada Nova sheep breeds (Waheed et al., 2016; Rashad et al., 2017; Paro de Paz et al., 2018). In addition, studies conducted by Hoijati and Hossein-Zadeh (2018), Ali et al. (2020), Bangar et al. (2018), Mohammadi et al. (2019), and HosseinZadeh and Golshani (2016) found that the Brody and Richards models were the best non-linear functions to describe the growth of Deccani, Mehraban, Kordi, Kajli and Iranian Guilan sheep, respectively. However, these models did not show convergence in the present study.

As previously reported by Hossein-Zadeh and Golshani (2016), Paro de Paz et al. (2018) and Ali et al. (2020), the Von Bertalanffy model showed the highest value for the parameter A (asymptotic weight), and the lowest value for the parameter $k$ (maturation rate), indicating the growth speed to reach asymptotic weight. Conversely, the Logistic model showed the lowest value for the parameter $\mathrm{A}$ and the highest value for parameter $\mathrm{k}$ (Table 2).

Fig. 1 shows that early growth of lambs has a linear trend and similarity in the fit of all the models used. The growth curves generated by the Gompertz and Von Bertalanffy models tend to overestimate body weight from the start to the middle of the evaluated period, while those of the Logistic and Linear models keep a greater correspondence with the observed weights.

For the Von Bertalanffy and Gompertz models, the parameter A was higher in multiple born males and quadruplet born females, while it was higher in males in the Logistic model. For all the non-linear models, the parameter $\mathrm{k}$ was higher in single and twin females, and single males (Table 3). These results coincide with those of Ali et al. (2020) who found that the parameter A was higher in male than in female lambs, and in triplet and twin rather than single lambs. They also reported that the parameter $\mathrm{k}$ was higher in females, and in single males.

Growth curves from all non-linear models show that from birth up to 90 days of age (weaning), weight of single lambs becomes greater than that of multiple born lambs (Fig. 2). Until weaning, the amount of milk available during lactation explains the difference in growth between single and multiple-born lambs (Mellado et al., 2016). Doney et al. (1984) indicated that $70 \%$ of the difference in weight gain from 3 to 12 weeks can be attributed to milk intake. From 90 days of age, weight of multiple born lambs tends to equal that of singles, which occurs at 180 days of age as previously observed by Macedo and Arredondo (2008). In the case of females, weight shows the same trend as that of males. However, at six months of age, weight of single females continues to be greater than that of multiple born females. Some authors have described that lambs that suffered a nutritional restriction during lactation - in this study by competition - show

Table 2. Estimated parameters of the Gompertz, Logistic and Von Bertlanffy models for Pelibuey lambs.

\begin{tabular}{lccc}
\hline Model & A & B & k \\
\hline Gompertz & $58.512 \pm 1.807$ & $1.036 \pm 0.010$ & $0.011 \pm 0.000$ \\
Logistic & $45.125 \pm 0.715$ & $2.272 \pm 0.025$ & $0.022 \pm 0.000$ \\
Von Bertalanffy & $74.047 \pm 3.544$ & $0.649 \pm 0.004$ & $0.007 \pm 0.000$ \\
\hline
\end{tabular}

A: predicted asymptotic weight at maturity $(\mathrm{kg})$; B: Integration constant to which initial weight is related or animal maturation rate at birth $(\mathrm{kg}) ; \mathrm{k}$ : Maturation rate. 




Fig. 1. Observed and predicted body weights $(\mathrm{kg})$ as a function of age obtained with the Gompertz, Logistic, Von Bertalanffy and Linear models for all lambs.

Table 3. Estimated parameters of the Von Bertalanffy, Gompertz and Logistic models for Pelibuey lambs according to litter size and sex.

\begin{tabular}{llccc}
\hline Model & Litter size/sex & $\mathbf{A} \pm$ se & B \pm se & k \pm se \\
\hline Von Bertalanffy & Single female & $46.256 \pm 4.534$ & $0.569 \pm 0.028$ & $0.012 \pm 0.002$ \\
& Twin female & $52.070 \pm 3.088$ & $0.605 \pm 0.009$ & $0.009 \pm 0.001$ \\
& Triplet female & $64.045 \pm 5.254$ & $0.643 \pm 0.008$ & $0.007 \pm 0.001$ \\
& Quadruplet female & $91.116 \pm 26.894$ & $0.705 \pm 0.020$ & $0.005 \pm 0.001$ \\
& Single male & $57.795 \pm 9.582$ & $0.596 \pm 0.036$ & $0.010 \pm 0.002$ \\
& Twin male & $87.249 \pm 7.303$ & $0.648 \pm 0.008$ & $0.007 \pm 0.001$ \\
& Triplet male & $100.363 \pm 11.004$ & $0.681 \pm 0.008$ & $0.006 \pm 0.001$ \\
& Quadruplet male & $113.887 \pm 26.168$ & $0.714 \pm 0.015$ & $0.005 \pm 0.001$ \\
\hline Gompertz & Single female & $42.846 \pm 3.302$ & $0.859 \pm 0.071$ & $0.015 \pm 0.002$ \\
& Twin female & $45.469 \pm 1.939$ & $0.939 \pm 0.024$ & $0.013 \pm 0.001$ \\
& Triplet female & $51.172 \pm 2.746$ & $1.020 \pm 0.018$ & $0.011 \pm 0.001$ \\
& Quadruplet female & $59.668 \pm 9.638$ & $1.149 \pm 0.037$ & $0.009 \pm 0.001$ \\
& Single male & $52.039 \pm 6.438$ & $0.923 \pm 0.094$ & $0.014 \pm 0.003$ \\
& Twin male & $69.067 \pm 3.755$ & $1.032 \pm 0.018$ & $0.010 \pm 0.001$ \\
& Triplet male & $72.335 \pm 4.741$ & $1.102 \pm 0.017$ & $0.010 \pm 0.001$ \\
& Quadruplet male & $75.355 \pm 9.527$ & $1.177 \pm 0.030$ & $0.009 \pm 0.001$ \\
\hline Logistic & Single female & $38.678 \pm 2.049$ & $1.916 \pm 0.147$ & $0.027 \pm 0.003$ \\
& Twin female & $38.499 \pm 0.966$ & $2.079 \pm 0.053$ & $0.024 \pm 0.001$ \\
& Triplet female & $39.795 \pm 1.116$ & $2.237 \pm 0.045$ & $0.022 \pm 0.001$ \\
& Quadruplet female & $40.061 \pm 2.803$ & $2.505 \pm 0.091$ & $0.022 \pm 0.002$ \\
& Single male & $45.571 \pm 3.510$ & $2.052 \pm 0.207$ & $0.025 \pm 0.004$ \\
& Twin male & $53.342 \pm 1.510$ & $2.263 \pm 0.046$ & $0.022 \pm 0.001$ \\
& Triplet male & $51.879 \pm 1.632$ & $2.405 \pm 0.043$ & $0.022 \pm 0.001$ \\
& Quadruplet male & $51.117 \pm 2.809$ & $2.588 \pm 0.081$ & $0.022 \pm 0.001$ \\
\hline
\end{tabular}

A: Predicted asymptotic weight at maturity $(\mathrm{kg})$; B: Integration constant to which initial weight is related or animal maturation rate at birth $(\mathrm{kg}) ; \mathrm{k}$ : Maturation rate. 

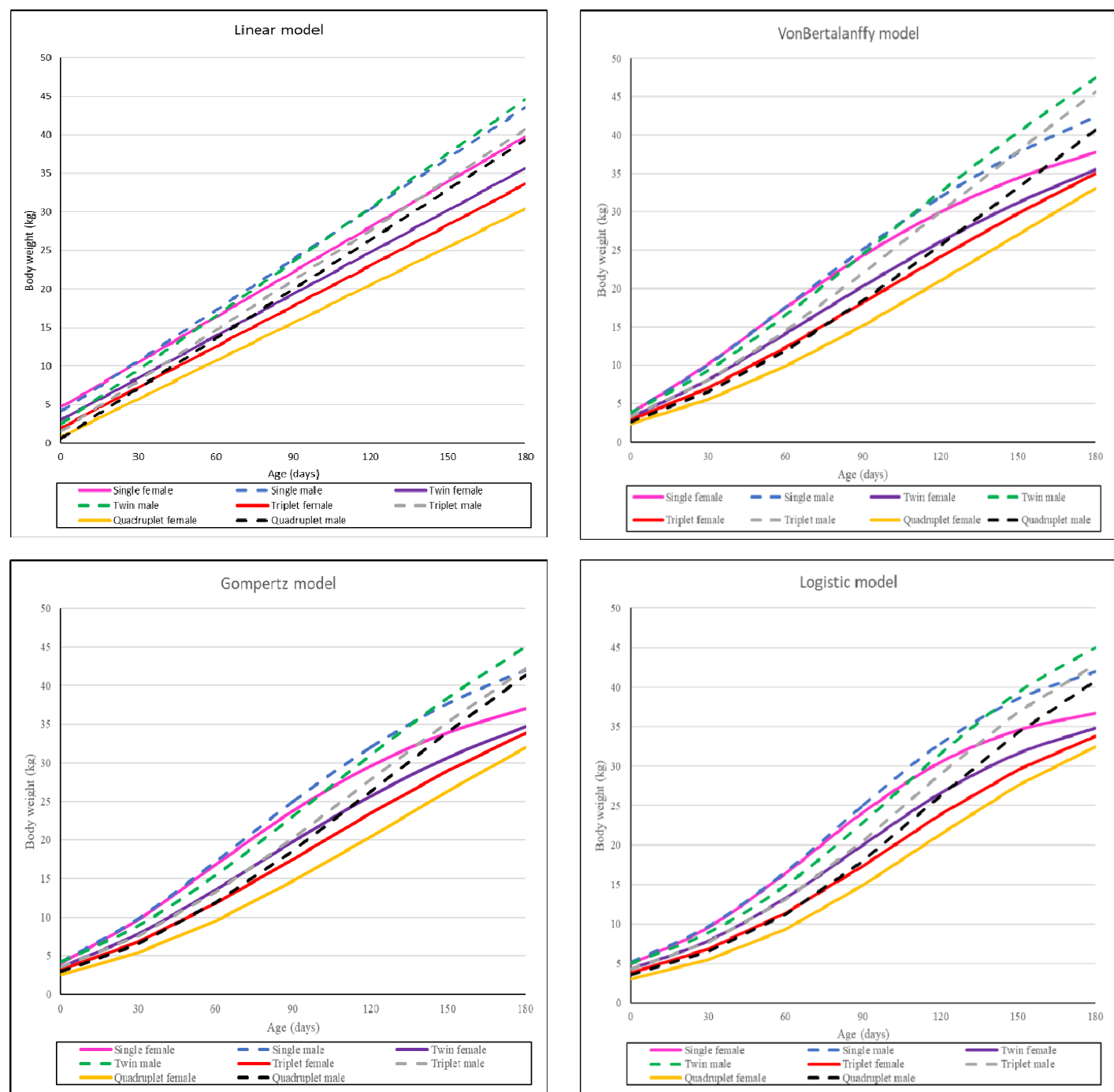

Fig. 2. Predicted body weights $(\mathrm{kg})$ as a function of age (days) obtained with the Linear, Von Bertalanffy, Gompertz and Logistic models for Pelibuey lambs.

compensatory growth once they are weaned and fed with concentrated feed (Cui et al., 2018; Santos et al., 2018). However, the results of the present study indicate that creep-fed does not completely compensate for the deficiency of maternal milk suffered during lactation in multiple born lambs. In addition, weight increases with age at a higher rate in males than females, which according to Hafez et al. (2000) is mainly explained by the production of testosterone that acts as an anabolic hormone.

It is important to note that if the trend of the non-linear growth curves continues, body weight of multiple born lambs would exceed that of the single lambs. However, this never occurs because single lambs reach a higher weight at maturity than twin, triplet and quadruple born lambs. Conversely, the linear model shows that the difference in weight gain between singles, twins, triplet and quadruplet born lambs increases with age. Likewise, the linear model demonstrates that the difference in weight of females is definitely influenced by litter size since it can be observed that weight of single females is similar to that of triplet- and quadruplet born males at 180 days of age.

The results of the present study show that, despite the lower birth weight and pre-weaning growth rate of multiple born lambs, particularly triplets and quadruplets, intensive management of a prolific breed such as the Pelibuey allows for a significant increase in meat production and the number of replacement ewes in a similar period, improving profitability of the production units.

Daily weight gain is commonly used as a productive parameter based on the assumption 
that growth in the first productive stages is linear. However, this constitutes a methodological error as it is based on arithmetic rather than statistical calculations. The use of mathematical modeling should be promoted, like the use a simple linear regression, which provides estimated values, means and residuals, as well as $\mathrm{R}^{2}$ and $\mathrm{P}$ values. Non-linear models, like complete sigmoid growth curves, can fit very well to early (linear) growth stages in which the animal reaches an asymptote. In this way, researchers can use nonlinear models for all growth stages, which is more in line with the biology of the animals.

\section{CONCLUSIONS}

The early growth of Pelibuey lambs raised under an intensive production system in Colima, Mexico, can be described with similar precision using linear and non-linear models. This allows the prediction of their productive performance for making better breeding and feeding decisions aimed at improving the productivity and economics of sheep farms.

\section{LITERATURE CITED}

Ali, A., K. Javed, I. Zahoor, and K.M. Anjum. 2020. Determination of the best non-linear function to describe the growth of Kajli sheep. South African Journal of Animal Science 50:452459. https://dx.doi.org/10.4314/sajas.v50i3.12

Bangar, Y.C., V.S. Lawar, R.G. Nimase, and C.A. Nimbalkar. 2018. Comparison of non-linear growth models to describe the growth behaviour of Deccani sheep. Agricultural Research 7(4):490-494. https:// doi.org/10.1007/s40003-018-0338-2

Cui, K., B. Wang, T. Ma, B.W. Si, N.F. Zhang, Y. Tu, et al. 2018. Effects of dietary protein restriction followed by realimentation on growth performance and liver transcriptome alterations of lamb. Scientific Reports 8:15185. https://doi.org/10.1038/s41598-018-33407-w

Doney, J.M., A.D.M. Smith, D.A. Sim, and D. Zygoyannis. 1984. Milk and herbage intake of suckled and artificially reared lambs at pasture as influenced by lactation pattern. Animal Science 38(2):191-199. https://doi. org/10.1017/S000335610000218X

González-Vázquez, J.A., I. Vázquez-Martínez, F. Enríquez-García, and L.M. Cuautle-García. 2015. Criterios de selección empleados en ovinos de reemplazo en sistemas tradicionales de la sierra norte de Puebla. Actas Iberoamericanas de Conservación Animal 6:286-293.
Hafez, E.S.E., M.R. Jainudeen, and Y. Rosnina. 2000. Hormones, growth factors, and reproduction. pp. 33-54. In B. Hafez, and E.S.E. Hafez (eds.) Reproduction in Farm Animal. Blackwell Publishing, South Carolina, USA.

Hernández-Bautista, J., T. Salinas-Ríos, H.M. Rodríguez-Magadán, C.M. Aquino, M.A. Mariscal, and M.I.Y. Ortiz. 2017. Características que determinan el sistema de producción ovina en el estado de Oaxaca, México. Revista Mexicana de Agroecosistemas 4(1):38-47.

Hernández-Montiel, W., M.A. Martínez-Núñez, J.P. Ramón-Ugalde, S.I. Román-Ponce, R. Calderón-Chagoya, and R. Zamora-Bustillos. 2020. Genome-wide association study reveals candidate genes for litter size traits in Pelibuey sheep. Animals 10:434. https://doi. org/10.3390/ani10030434

Hoijati, F., and N.G. Hossein-Zadeh. 2018. Comparison of non-linear growth models to describe the growth curve of Mehraban sheep. Journal of Applied Animal Research 46(1):499-504. https://doi.org/10.1080/097121 19.2017.1348949.

Hossein-Zadeh, N.G., and M. Golshani. 2016. Comparison of non-linear models to describe growth of Iranian Guilan sheep. Revista Colombiana de Ciencias Pecuarias 29:199-209. https://doi:10.17533/udea.rccp. v29n3a05.

Lupi, T.M., S. Nogales, J.M. León, C. Barba, and J.V. Delgado. 2015. Characterization of commercial and biological growth curves in the Segureña sheep breed. Animal 9(8):1341-1348. https://doi.org/10.1017/ S1751731115000567

Macedo, R., and A. Alvarado. 2005. Efecto de la época de monta sobre la productividad de ovejas pelibuey bajo dos sistemas de alimentación en Colima, México. Archivos de Zootecnia 54(205):51-62.

Macedo, R., and V. Arredondo. 2008. Efecto del sexo, tipo de nacimiento y lactancia sobre el crecimiento de ovinos Pelibuey en manejo intensivo. Archivos de Zootecnia 57(218):219228.

Macedo, B.R., R.V. Arredondo, R.R. Rodríguez, S.J.A. Rosales, and G.A. Larios. 2009. Effects of adding yeast culture and diet on in vitro degradation and productivity of Pelibuey lambs. Técnica Pecuaria en México 47(1):4153.

Martínez-Peña, M., J.A. Villagómez-Cortés, and A.H. Mora-Brito. 2018. Profitability of the sheep production system in the Bajo Mixe, Oaxaca, Mexico. Agrociencia 52:107-122. 
Mellado, J., V. Marín, J.L. Reyes-Carrillo, M. Mellado, L. Gaytán, and M.A. De Santiago. 2016. Effects of non-genetic factors on preweaning growth traits in Dorper sheep managed intensively in central Mexico. Ecosistemas y Recursos Agropecuarios 3(8):229-235.

Mohammadi, Y., M.S. Mokhtari, D.A. Saghi, and A.R. Shahdadi. 2019. Modeling the growth curve in Kordi sheep: The comparison of non-linear models and estimation of genetic parameters for the growth curve traits. Small Ruminant Research 177:117-123. https://doi. org/10.1016/j.smallrumres.2019.06.012

Paro de Paz, C.C., V.G. Costa, E. Contini, D.C.R. Lopes, L.P. Lameirinha, and C.R. Quirino. 2018. Nonlinear models of Brazilian sheep in adjustment of growth curves. Czech Journal of Animal Science 63(8):331-338. https://doi. org/10.17221/87/2017-CJAS

Rashad, A.M.A., T.A. Ramadan, and A.E. Mahdy. 2017. Comparison among models to describe growth curves of Rahmani lambs in relation to ewe milk yield and composition. Egyptian Journal of Animal Production 54(2):125-135.

Resendiz, C.V., O. Hernández, I. Guerrero, J. Gallegos, P.A. Martínez, and C. Sánchez. 2013. Engorda de corderos Pelibuey con diferente nivel de alfalfa en la dieta. Archivos de Zootecnia 62(239):457-467. https://doi. org/10.21071/az.v62i239.651

Santos, A., F.J. Giráldez, C. Valdés, E. Trevisi, L. Lucini, J. Frutos, and S. Andrés. 2018. Milk replacer restriction during early life impairs the live body weight and progesterone patterns of ewe lambs during the replacement period. Journal of Dairy Science 101:80218031. https://doi.org/10.3168/jds.2018-14648
SENASICA. 2019. Normas Oficiales Mexicanas en Materia de Salud Animal. Servicio Nacional de Sanidad, Inocuidad y Calidad Agroalimentaria (SENASICA), Ciudad de México, México. Disponible en https:// $\mathrm{www} \cdot \mathrm{gob} \cdot \mathrm{mx} / \mathrm{senasica/documentos/}$ normatividad-en-materia-de-saludanimal?idiom=es (Webaccess April 26, 2020).

Simanca, S.J., O.D. Vergara, and M.J. Bustamante. 2016. Description of growth in sheep Santa Ines $x$ Creole in extensive grazing in two populations from Cordoba, Colombia. Revista de la Facultad de Ciencias Veterinarias UCV 57:61-67.

Vázquez-Martínez, I., J.L. Jaramillo-Villanueva, A. Bustamante-González, S. Vargas-López, F. Calderón-Sánchez, G. Torres-Hernández, and W. Pittroff. 2018. Structure and typology of sheep production units in central México. Agricultura Sociedad y Desarrollo 15(1):8597.

Waheed, A., E. Eyduran, M.M. Tariq, S. Ahmad, T. Hameed, and F.A. Bukhari. 2016. Comparison of the non-linear models defining the growth of Thalli sheep under desert conditions. Pakistan Journal of Zoology 48(2):423-426. 